\title{
Original Research \\ Nutrient Fluxes and Their Impact on the Phytoplankton in a Shallow Coastal Lake
}

\author{
Magdalena Wielgat-Rychert ${ }^{1 *}$, Anna Jarosiewicz ${ }^{1}$, Dariusz Ficek², \\ Magdalena Pawlik², Krzysztof Rychert ${ }^{1}$
}

${ }^{1}$ Institute of Biology and Environmental Protection, ${ }^{2}$ Institute of Physics, Pomeranian University in Słupsk Arciszewskiego 22b, 76-200 Słupsk, Poland

Received: 14 August 2014

Accepted: 13 October 2014

\begin{abstract}
Data on nutrient concentrations and phytoplankton growth was analyzed in Lake Gardno, representing a separate group of coastal lakes within the Polish abiotic typology according to the Water Framework Directive. The aim of this work was to identify sources of nutrient variability in lake water and consequences of this variability for phytoplankton growth. Phytoplankton composition was dominated by green algae, present in high biovolumes throughout the year, and cyanobacteria, whose elevated biovolumes were noted at temperatures above $13^{\circ} \mathrm{C}$. Production of phytoplankton was often light-limited throughout the vegetation period (changing on a day-to-day basis). Low N-to-P ratio, the presence of nitrogen-fixing cyanobacteria, and Carlson's trophic state indices (TSI) analysis indicated also possible nitrogen limitations of primary production during the vegetation period. No phosphorus limitation was indicated. Possible nitrogen limitation was a result of in-lake modification of the N-to-P ratio compared to external N-to-P ratio in nutrient loads discharged by the freshwater inflow. Lake Gardno was a substantial sink of nitrogen discharged by the Łupawa River, probably due to denitrification. Nutrient budget for the 2006-08 period revealed 50\% loss of nitrogen in a lake, whereas the phosphorus budget did not reveal substantial phosphorus retention. From a management perspective, the study indicates the importance of reduction of phosphorus loads discharged to the lake, which could prevent further development of cyanobacterial blooms stimulated by low N-to-P ratio.
\end{abstract}

Keywords: nutrients, shallow lake, Lake Gardno, coastal lake, nitrogen limitation

\section{Introduction}

Nutrient status, mainly the availability of nitrogen and phosphorus, is essential to understand the present state of a lake ecosystem and to predict its possible further development and proper management strategies within the drainage basin [1]. Because each lake ecosystem is influenced by lake morphometry, basin geology, and climate, nutrient sources and nutrient cycling in lake waters differ between

*e-mail: wielgatm@wp.pl lakes [2]. Numerous case studies are needed to formulate more general patterns of lake ecosystem functioning in relation to their specific characteristics. Lake Gardno belongs to a type of shallow lake located along the southern Baltic Sea coast and influenced by seawater intrusions. Such coastal lakes were grouped separately within the Polish abiotic typology prepared according to the requirements of the Water Framework Directive 2000/60/EC [3]. It represents the type of lake which can be considered a "shallow" lake. Shallow lakes differ in their hydraulic behavior and ecological functioning from deep lakes. 
Table 1. Loads of nutrients to Lake Gardno.

\begin{tabular}{|c|c|c|c|c|c|c|}
\hline & \multicolumn{2}{|c|}{$\begin{array}{l}\text { Loads } \\
{\left[\mathrm{t} \cdot \mathrm{year}^{-1}\right]}\end{array}$} & \multicolumn{2}{|c|}{$\begin{array}{c}\text { Loads } \\
{[\%]}\end{array}$} & \multirow[t]{2}{*}{ Measurement period } & \multirow[t]{2}{*}{ References } \\
\hline & $\mathrm{N}$ & $\mathrm{P}$ & $\mathrm{N}$ & $\mathrm{P}$ & & \\
\hline Łupawa River & 862 & 39 & 80 & 80 & 2006-08 measured & [21] \\
\hline Other small rivers & 95 & 3.3 & 9 & 7 & 2008 measured & [14] \\
\hline Atmospheric input & 24 & 1.2 & 2 & 2 & 2008 measured & {$[25]$} \\
\hline Surface runoff & 37 & 1.2 & 3 & 2 & 2008 estimated & {$[25]$} \\
\hline Groundwater inflow & 54 & 2.8 & 5 & 6 & 2008 estimated & {$[25]$} \\
\hline Seawater inflow & 11 & 1.2 & 1 & 2 & 2008 estimated & {$[25]$} \\
\hline Total & 1083 & 48.7 & 100 & 100 & & \\
\hline
\end{tabular}

They are polymictic, usually more productive because bottom sediments close to the euphotic layer facilitate nutrient and organic matter recycling, commonly without such distinct seasonality in plankton succession as observed in temperate climates in deep waters $[4,5]$.

In the present work we analyzed data on nutrient cycling, phytoplankton growth, and composition in Lake Gardno. The aim was to describe the present trophic status of the lake, to identify sources of nutrient variability in lake water in relation to inflowing concentrations, and consequences of this variability for phytoplankton growth. Recently little information was published about phytoplankton of Polish coastal lakes with the exception of work by the Burchardt et al. [6], who presented phytoplankton composition. Trophic conditions of these lakes were studied recently by Szyper and Jarosiewicz [7, 8], but most information comes from the 1980s and early 1990s, $[9,10]$ and is not extensive.

Lake Gardno $\left(54^{\circ} 39^{\prime} \mathrm{N}, 17^{\circ} 07^{\prime} \mathrm{E}\right)$ is a shallow flowthrough lake with a mean depth of $1.2 \mathrm{~m}$. The lake is polymictic because of its small depth and pan-shaped bottom. The large surface area $\left(24.68 \mathrm{~km}^{2}\right)$ located next to the coast of the Baltic Sea is exposed to winds. Because the lake is directly connected to the sea, it is partly brackish. The Baltic Sea is non-tidal, so seawater intrusions occur on an irregular basis depending on the wind speed, wind direction, and freshwater inflow $[11,12]$. The seawater inflow forms no permanent vertical salinity gradient, but only a horizontal gradient in the lake waters [12]. Salinity, measured in the center of the lake (station 1, Fig. 1), varied from 0.17 to $1.60 \%$, indicating seawater inflows, but the average $(0.66 \%)$ remained low compared to the surface salinity of the southern Baltic Sea coast, which is about 7.5\%o [13].

The Łupawa River introduces about $90 \%$ of the freshwater inflow to the lake [11], which during 2006-08 amounted to $9.3 \mathrm{~m}^{3} \cdot \mathrm{s}^{-1}$. In order to calculate nutrient budgets of the lake, other sources, such as atmospheric deposition and groundwater input were summarized in Table 1. Nutrient loads of "other small rivers" in tons per year were calculated on the basis of measurements done by Cieśliński [14]. The author studied nutrient loads of small inflows dur- ing the 2008 vegetation period and concluded that small inflows introduced $10.1 \%$ of the entire $\mathrm{N}_{\text {tot }}$ load and $7.4 \%$ of the entire $\mathrm{P}_{\text {tot }}$ load discharged to Lake Gardno by surface waters during this period. One source which is not entirely included in Table 1 is water pumped from polder areas in the immediate drainage basin of the lake. In part, this water is pumped directly to the lake and partly to small rivers and canals listed in Table 1 as 'other small rivers'. Capacity of pumping stations is relatively high (about $3.8 \mathrm{~m}^{3} \cdot \mathrm{s}^{-1}$ ), but the real amount of water discharged to the lake depends on the time of pumping stations' work. According to Ellwart and Cieśliński [15], the amount of water pumped from the largest polder in 2006 was less than $25 \%$ of pumping station capacity. This source would be of importance if concentrations in the pumped water were high. There is however, no indication of elevated nutrient concentrations. In general, nutrient concentrations in small inflows, where water was pumped from polder areas, were in the range of

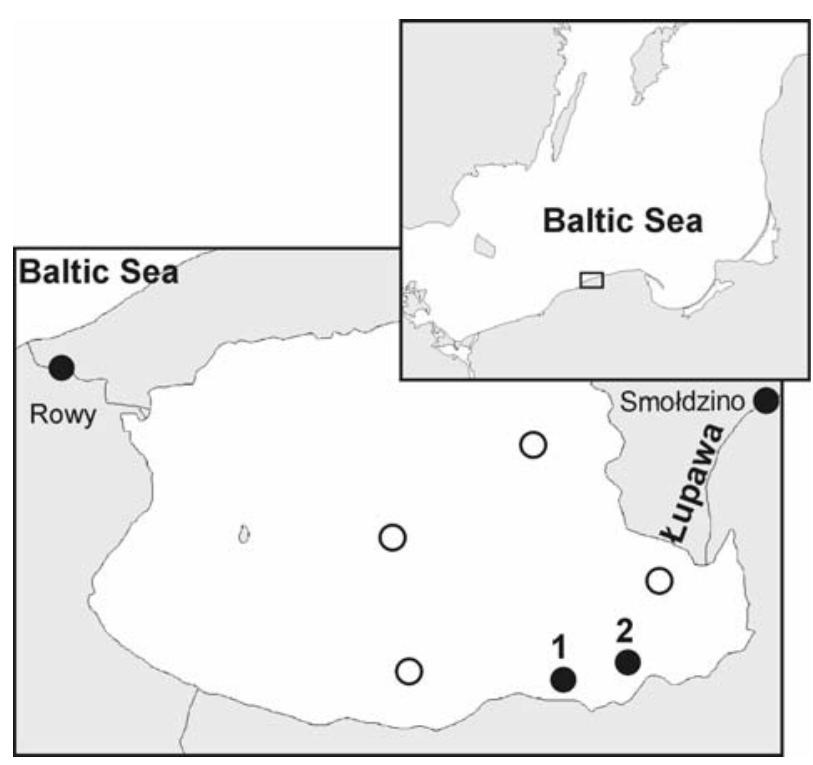

Fig. 1. Location of sampling sites: sampling site 1, site 2, and sampling sites for nutrient measurements conducted in 2006 (open circles). 
Table 2. Pearson's correlation matrix of nutrient, TSM, and Chl $a$.

\begin{tabular}{|c|c|c|c|c|c|c|}
\hline & $\mathrm{P}_{\text {org }}$ & $\mathrm{P}_{\text {tot }}$ & $\mathrm{N}_{\text {org }}$ & $\mathrm{N}_{\text {tot }}$ & Chl & TSM \\
\hline $\mathrm{P}_{\text {org }}$ & 1.00 & 0.92 & $\mathrm{~ns}$ & $\mathrm{~ns}$ & 0.67 & 0.78 \\
\hline $\mathrm{P}_{\text {tot }}$ & & 1.00 & $\mathrm{~ns}$ & $\mathrm{~ns}$ & $\mathrm{~ns}$ & 0.62 \\
\hline $\mathrm{N}_{\text {org }}$ & & & 1.00 & $\mathrm{~ns}$ & 0.56 & $\mathrm{~ns}$ \\
\hline $\mathrm{N}_{\text {tot }}$ & & & & 1.00 & $\mathrm{~ns}$ & $\mathrm{~ns}$ \\
\hline $\mathrm{Chl}$ & & & & & 1.00 & 0.89 \\
\hline $\mathrm{TSM}$ & & & & & & 1.00 \\
\hline
\end{tabular}

$\mathrm{p}<0.05, \mathrm{~ns}-$ non-significant

concentrations in the Łupawa River [14]. Thus, we assume this underestimation is not critical for budget calculations.

\section{Material and Methods}

Measurements were performed in the 2006-08 period at one site marked as station 1 in Fig. 1 (with the exception of nutrient measurements, see below). This measurement site was located far enough from the shoreline to represent an open-water area of a lake [16]. The water column in the lake is usually very homogeneous [16], therefore only subsurface samples were collected.

Nutrients were measured once a month (FebruaryDecember). In 2006 nutrients were measured at site 1 and 4 other locations within the southeastern part of the lake (Fig. 1). In 2007 measurements were carried out at site 1 and in 2008 at site 2 (Fig. 1). Altogether 56 samples were collected. The following nutrient forms were measured: ammonium $\left(\mathrm{NH}_{4}\right)$, nitrate + nitrite $\left(\mathrm{NO}_{3}\right)$, total nitrogen $\left(\mathrm{N}_{\text {tot }}\right)$, inorganic phosphorus $\left(\mathrm{PO}_{4}\right)$, and total phosphorus $\left(\mathrm{P}_{\text {tot }}\right)$, with use of standard colorimetric methods [17]. Amounts of organic forms of nitrogen $\left(\mathrm{N}_{\text {org }}\right)$ and phosphorus $\left(\mathrm{P}_{\mathrm{org}}\right)$ were calculated as the difference between concentrations of total and mineral forms. The $\mathrm{N}$ to $\mathrm{P}$ ratio was calculated in $\mathrm{g} / \mathrm{g}$ (mass ratio).

Measurements of chlorophyll a $(\mathrm{Chl} a)$, total suspended matter (TSM), conductivity, temperature, and PAR were performed from February to December, twice a month in 2006 and once a month in 2007 and 2008 (n=24).
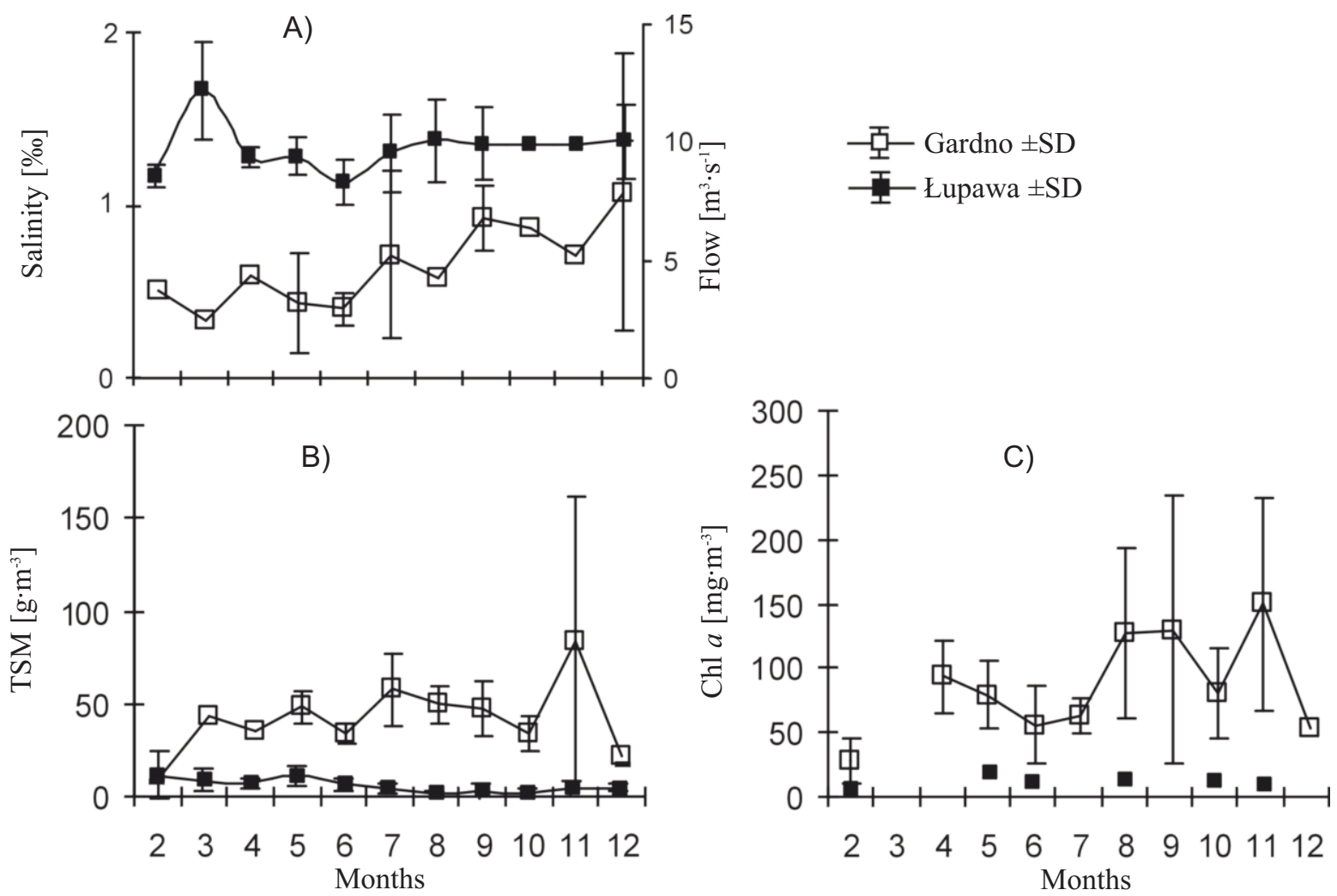

Fig. 2. (A) Average monthly salinity in Lake Gardno and the Łupawa River flow. Data on the Lupawa River [21, 22]. (B) Seasonal changes in TSM and (C) Chl $a$ mean monthly concentrations in Lake Gardno and in the Łupawa River. In the Łupawa River variability in concentrations is not always visible due to low variability compared to lake waters. 
Conductivity (in $\mathrm{mS} \cdot \mathrm{cm}^{-1}$ ) was measured by the conductometric method and recalculated into salinity (\%o) with a coefficient of 0.5 . Chlorophyll $a(\mathrm{Chl} a)$ was extracted from Whatman GF/F glass-fiber filters with $90 \%$ acetone solution for $24 \mathrm{~h}$ in the dark at $4-6^{\circ} \mathrm{C}$ and was measured with a standard spectrophotometric method without correction for phaeopigments [18]. Total suspended matter values (TSM) were obtained by filtering known amounts of water through Whatman GF/F glass-fiber filters, which were dried to a constant weight. Measurements of primary production were performed with oxygen method at site 1 and the measurement details and results for the 2006-07 period were described elsewhere [19]. The light extinction coefficient $(\mathrm{Kd})$ was measured from June 16, 2006 to November 12, 2007. The underwater light fields were measured with a spectroradiometer Satlantic and the attenuation coefficient of downward irradiance $(\mathrm{Kd})$ was calculated.
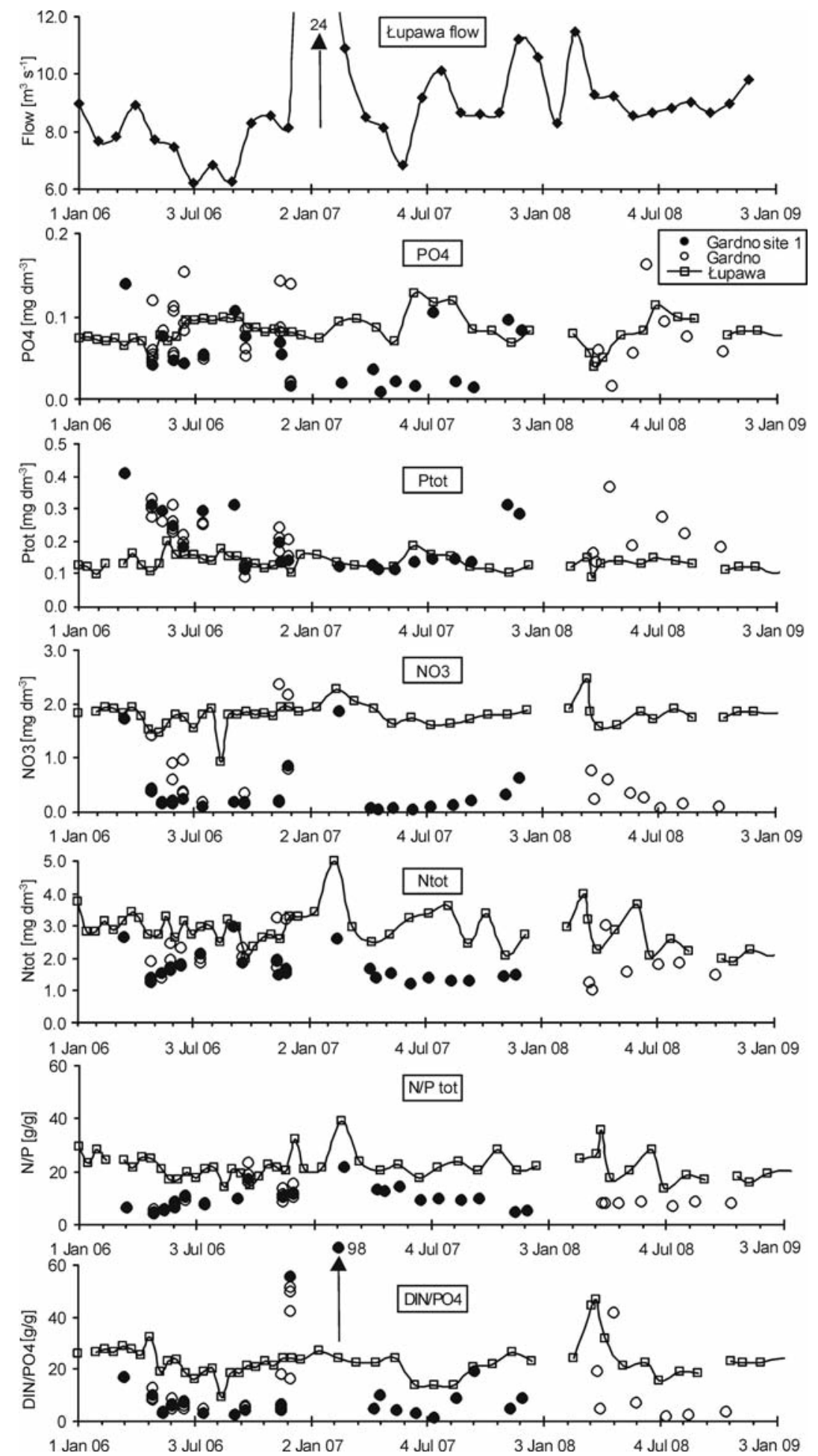

Fig. 3. Nutrient concentrations in Lake Gardno and in the Łupawa River [21, 22] (for station location see Fig. 1). 
Table 3. Nutrient and chlorophyll $a$ budget of Lake Gardno.

\begin{tabular}{|c|c|c|c|}
\hline & Input $\left[\mathrm{t} \cdot \mathrm{year}^{-1}\right]$ & Outpt [t.year $\left.{ }^{-1}\right]$ & Reduction/Increase \\
\hline $\mathrm{P}_{\text {tot }}$ & 48.7 & 62 & 1.26 \\
\hline $\mathrm{N}_{\text {tot }}$ & 1083 & 531 & 0.49 \\
\hline $\mathrm{Chl}$ & $2.1^{*}$ & 25 & 11.7 \\
\hline
\end{tabular}

* concentration only in the Lupawa River

Phytoplankton composition and biovolume was measured in 2006 and 2007 (n=22), twice a month in 2006 and once a month in 2007 . Water samples $(200 \mathrm{ml})$ were fixed with acidic Lugol's solution to a final concentration of $0.5 \%$. Phytoplankton was analyzed with use of an inverted microscope (PZO) following the Utermöhl method. The individual phytoplankton cells were counted and the biovolume was calculated using appropriate shape formulas [20].

All data from the Łupawa River was collected as part of the Polish monitoring program by the Inspectorate of Environmental Protection in Słupsk with standard methods used in monitoring according to the Water Framework Directive 2000/60/EC [3]. Data for the present paper was obtained from annual monitoring reports [21]. Nutrient concentrations in the Lupawa River at the last monitoring station before the entrance to the lake (in Smołdzino; Fig. 1 ), were measured twice a month in 2006, and once a month in 2007 and 2008. Chl $a$ was measured only a few times a year in 2006 and 2007 [21]. Most methods were comparable to those used for measurements in Lake Gardno with an exception for $\mathrm{Chl} a$, which was corrected for phaeopigments in the Lupawa River. Athough these two methods produced slightly different results (unpublished), the differences were not so substantial as to alter the final conclusions presented in the discussion. The mean month-

Depth of the euphotic layer

Secchi depth visibility

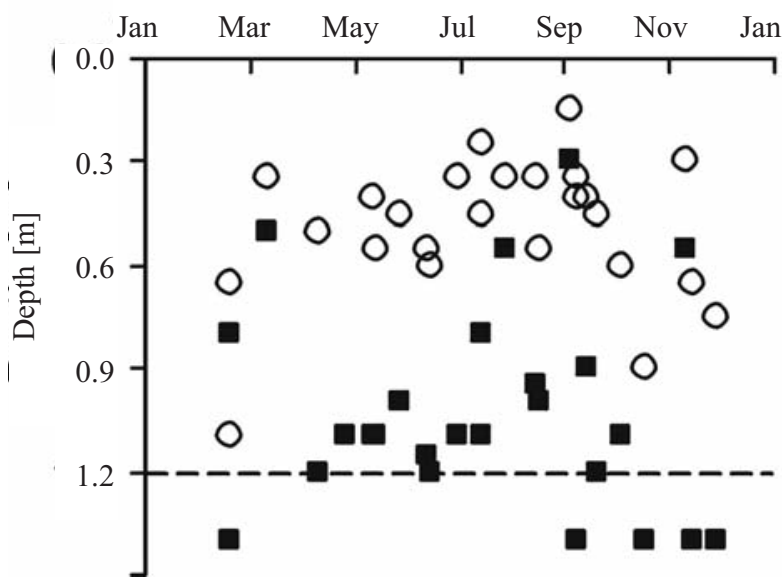

Fig. 4. Seasonal changes of water transparency measured as Secchi depth visibility and depth of the euphotic zone. Dashed line indicates average depth of Lake Gardno. ly flow data for the Lupawa River at Smołdzino was obtained from monthly monitoring bulletins [22].

Statistical analyses were performed with Statistica 10.0 (Statsoft).

\section{Results}

\section{Water Budget}

The mean monthly flow in the Łupawa River did not reveal any clear seasonality during the measurement period (Fig. 2A) but was characterized by year-to-year differences (Fig. 3). In the 2006-08, the average monthly flow was 9.3 $\mathrm{m}^{-3} \cdot \mathrm{s}^{-1}$, with one extremely high winter value up to $24 \mathrm{~m}^{-3} \cdot \mathrm{s}^{-1}$ in January 2007 (Fig. 3). The lowest flow was measured during the vegetation period of 2006, particularly from July to September, when the average monthly flow was by 30 $40 \%$ lower than the three-year average (Fig. 3). The average freshwater retention time calculated for the average lake volume amounted to 39 days.

Salinity in Lake Gardno ranged from 0.17 to $1.60 \%$ with an average value of $0.66 \%$ and was treated as a proxy of seawater intrusions (Fig. 2A). Smallest inflows of marine waters were measured during high river discharge in spring (Fig. 2A), whereas larger marine inflows occurred during summer and winter low-flow periods.

\section{Chlorophyll and TSM Concentrations}

Chl $a$ and TSM contents in the Łupawa River were, on average, lower than in the lake and relatively stable throughout the year, with low year-to-year variation. TSM and $\mathrm{Chl} a$ concentrations in the lake were variable and high throughout the entire vegetation period (Fig. 2B and 2C), with Chl $a$ ranging from 10.9 to $303 \mathrm{mg}^{-3}$ and TSM from 7.6 to $133 \mathrm{~g} \cdot \mathrm{m}^{-3}$. TSM and Chl $a$ were correlated (Table 2).

\section{Light and Water Transparency}

Secchi depth remained within a range of 0.2 to $0.6 \mathrm{~m}$ throughout the vegetation period (Fig. 4). Values of light extinction coefficient $(\mathrm{Kd})$ ranged from 2.8 to $11.7 \mathrm{~m}^{-1}$. Thickness of the euphotic layer estimated from measurements of primary production was weakly positively correlated to PAR $\left(\mathrm{R}^{2}=0.21, \mathrm{n}=21, \mathrm{p}=0.035\right)$, and negatively correlated to TSM $\left(\mathrm{R}^{2}=0.46, \mathrm{n}=17, \mathrm{p}=0.003\right)$ and Chl $a$ $\left(\mathrm{R}^{2}=0.55, \mathrm{n}=19, \mathrm{p}=0.0003\right)$.

\section{Phytoplankton}

A relatively high biomass of green algae was present throughout the years with higher biovolumes noted during the vegetation period. High diatom biovolumes were noted at lower temperatures, e.g in fall 2006 (Fig. 5). Elevated biovolumes of cyanobacteria were noted at temperatures above $13^{\circ} \mathrm{C}$ and they were higher in 2006 than in 2007, differing by dominant species. Namely, in 2006 Microcystis 
sp. dominated, whereas in 2007 species from the Oscillatoriaceae dominated. Low biovolumes of other groups of algae are not shown in Fig. 5.

\section{Nutrients}

Nutrient concentrations in the Lupawa River were relatively stable, without distinct seasonal differences and with low year-to-year variation (Fig. 3). The average $\mathrm{N}_{\text {tot }} / \mathrm{P}_{\text {tot }}$ mass ratio amounted to 21 (range 14-39) and was relatively stable throughout the year, whereas the average $\mathrm{NO}_{3} / \mathrm{PO}_{4}$ mass ratio amounted to 23 (range 9-47).

Nutrient concentrations in the lake and its main tributary, the Łupawa River, were not correlated. Seasonal trends for nitrogen and phosphorus concentrations in Lake Gardno differed. $\mathrm{P}_{\text {tot }}$ and $\mathrm{PO}_{4}$ concentrations did not reveal any specific trend during the vegetation period (Fig. 3). Additionally, the seasonal pattern was different in each year, some concentrations were lower than in the river and some were higher. During vegetation periods both $\mathrm{NO}_{3}$ and $\mathrm{N}_{\text {tot }}$ concentrations were much lower in Lake Gardno than in the Lupawa River. The average $\mathrm{N}_{\text {tot }} / \mathrm{P}_{\text {tot }}$ mass ratio in lake water amounted to 10 (range 4-23). Especially $\mathrm{NO}_{3}$ concentrations decreased substantially each year during the vegetation period. Highest DIN-to- $\mathrm{PO}_{4}$ mass ratios (up to 98) were noted only in winter months, while during vegetation periods most values dropped below 7 (Fig. 3). $\mathrm{P}_{\text {org }}$ and $\mathrm{N}_{\text {org }}$ concentrations were correlated with Chl $a$ concentrations in the water (Table 2). For Lake Gardno, Carlson's trophic state indices (TSI) ranged from 60.6 $\mathrm{TSI}_{\mathrm{Ntot}}$ to 82.6 $\mathrm{TSI}_{\text {Ptot}}$.

\section{Nutrient and Chlorophyll Budget}

A comparison of nutrient and chlorophyll concentrations in the river water and in the lake water allows us to draw certain conclusions about the nutrient and chlorophyll budget of Lake Gardno. Table 3 presents a calculation of the Chl $a$ and nutrient budget for Lake Gardno. Incoming loads were calculated in Table 1, whereas loads exported from the lake to the Baltic Sea were calculated as a product of the average annual river water outflow and the average monthly concentration in the lake, providing that this was the concentration in the outflowing water. Such a budget is only a rough approximation of real fluxes as sources other than the Lupawa River are only estimated and not measured during 2006-08 (Table 1).

\section{Discussion}

We estimate the Łupawa River to be the main source of all constituents (e.g. nutrients) to the lake among all other sources considered in Table 1. On average, the Lupawa River discharged about $80 \%$ of $\mathrm{N}_{\text {tot }}$ and $\mathrm{P}_{\text {tot }}$ (Table 1). Low salinity indicated relatively small addition of seawater at measurement site 1. Marine water inflows result from a difference between the Baltic Sea water level and the water level in the inflowing river. As discussed e.g. in [12], also for the neighboring lakes, the smallest inflows of marine waters were measured during high river discharge in spring (Fig. 2A), whereas larger marine inflows occurred during summer and winter low-flow periods.

\section{Chlorophyll Budget}

Inflow of the river water into the vast Lake Gardno basin provided better conditions for phytoplankton growth. This was reflected by much higher Chl $a$ content in the lake than in the Lupawa. Calculation of the Chl $a$ load exported from the lake to the Baltic Sea yields a load over 10 times higher than input load (Table 3). Thus, Lake Gardno is a source of organic matter to the sea as due to it more phytoplankton is further exported to the Baltic Sea than would be exported by Łupawa waters alone. Differences in measurement methods (mentioned in Material and Methods) cannot be responsible for such a high change. Also, additional

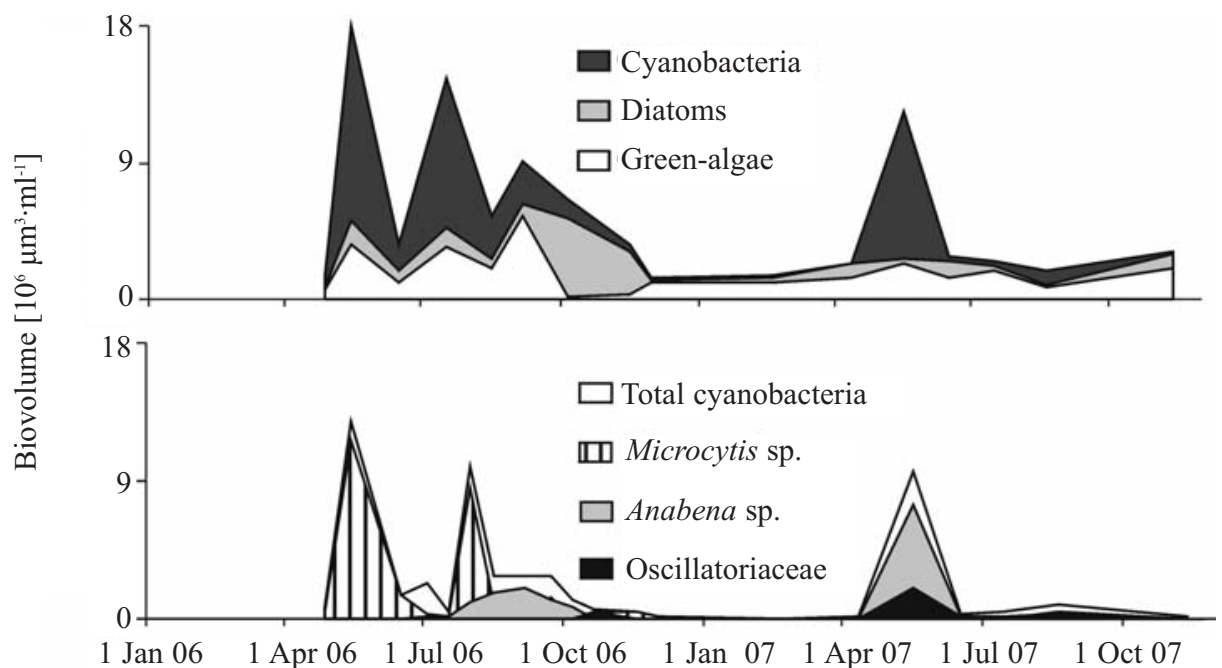

Fig. 5. (A) Seasonal changes in biovolume of main phytoplankton groups, low biovolumes of other groups of algae are not shown. (B) Biovolume of most common groups of cyanobacteria. 
input from smaller inflows is unlikely to produce such substantial differences as discussed below for nutrients.

\section{Nutrient Budget}

Nutrient budgets differed for nitrogen and phosphorus compounds. Although the Łupwa River introduces about $90 \%$ of the water inflow to the Lake [11], there was no correlation between monthly nutrient concentrations in the river and in the lake waters during the study period. $\mathrm{P}_{\text {tot }}$ and $\mathrm{PO}_{4}$ concentrations in the lake were at the same level (or higher) as those in the river, while each year the seasonal pattern was different. Inorganic nutrient concentrations in lake water are influenced by uptake and release. Higher summer $\mathrm{PO}_{4}$ concentrations in the lake than in the river could be an indication of "internal loading" of $\mathrm{PO}_{4}$ from the sediments as at high temperatures, phosphorus flux from organic-rich sediments can be expected [23, 24]. However, such a regular seasonal pattern was not observed as, in general, phosphorus concentrations revealed strong variation. However, Trojanowski [9], who measured phosphorus content in the sediment during the vegetation period in 1986, noted a decrease in summer.

With an average depth of $1.2 \mathrm{~m}$, Lake Gardno belongs to the type of shallow polymictic lakes that are known to be very dynamic. Without seasonal stratification typical for deeper lakes in a temperate climate, they encounter fluctuations in physical and biological parameters within their productive zone due to wind-driven mixing $[4,5]$. An example can be the day-to-day variation in Chl $a$ content described in Lake Gardno by Ficek and Wielgat-Rychert [16], where in September the concentration dropped from 303 to $165 \mathrm{mg} \mathrm{m}^{-3}$ from one day to another. Such high TSM and Chl $a$ concentrations in late fall indicated events of strong winds inducing resuspension of sediment. In general, organic nutrient concentrations in Lake Gardno water

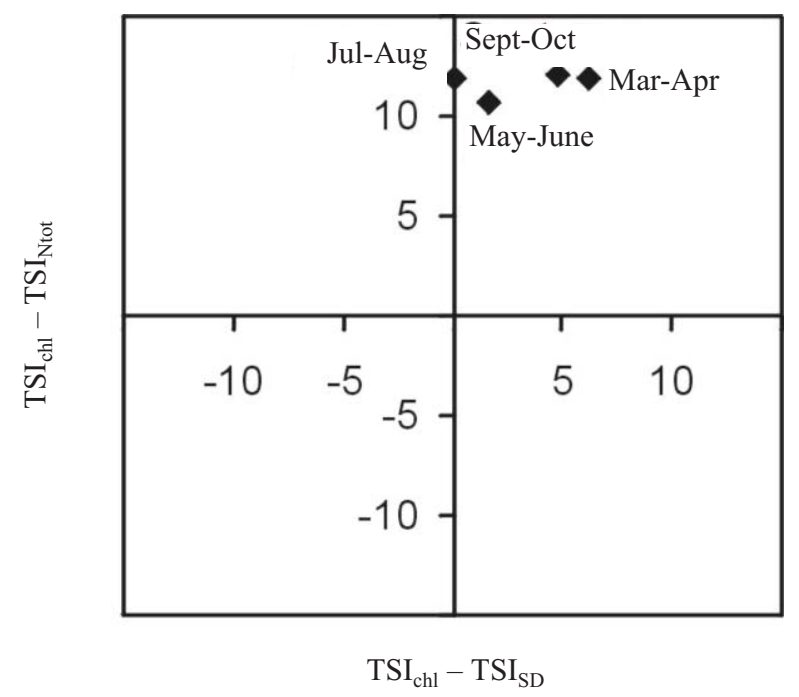

Fig. 6. Seasonal differences in mean $(n=8-11)$ TSI values of lake Gardno in 2006-08. were best explained by TSM and Chl $a$ concentrations in the water column. $\mathrm{P}_{\text {org }}$ and $\mathrm{N}_{\text {org }}$ concentrations were correlated with $\mathrm{Chl} a$ concentrations in the water (Table 2). $\mathrm{P}_{\text {tot }}$ and $\mathrm{P}_{\text {org }}$ were also correlated to TSM concentrations (Table 2 ), but such correlations for nitrogen compounds were not found. We conclude that $\mathrm{P}_{\text {tot }}$ correlation with TSM indicates that phosphorous bound in surface sediment under toxic conditions was resuspended from the bottom, and thus additional amounts of sediment-bound forms of phosphorus were present in pelagic water.

Another cause of fluctuations was variation in the fresh water retention time, also influencing the water level in the lake. Much lower inflow of riverine water during the vegetation period of 2006 resulted in longer freshwater retention time and also possibly lower water levels in the lake. A lower water level could increase resuspension events and thus be responsible for higher $\mathrm{P}_{\text {tot }}$ and $\mathrm{PO}_{4}$ concentrations in the water in 2006. Average $\mathrm{P}_{\text {tot }}$ and $\mathrm{PO}_{4}$ concentrations (April-October) were almost 2 times higher in 2006 than in 2007 (Fig. 4) as described also by Jarosiewicz [8].

The average annual phosphorus budget was balanced without retention of phosphorus within the lake.A rough calculation of $\mathrm{P}_{\text {tot }}$ load exported from the lake to the Baltic Sea as the product of the average annual river water outflow and the average annual $\mathrm{P}_{\text {tot }}$ concentration in the lake water $\left(0.21 \mathrm{mg} \cdot \mathrm{dm}^{-3}\right)$ gives about $20 \%$ higher result than the total load entering the lake from the drainage area. A similar conclusion about small phosphorus retention capacity was reached also by Wiśniewska [25], who estimated the retention of phosphorus in the lake equal to $10 \%$ of the incoming load in 2008, based on concentrations measured in the lake outlet in Rowy (Fig. 1).

Unlike $\mathrm{PO}_{4}$ concentration, $\mathrm{NO}_{3}$ concentrations decreased substantially each year during the vegetation period, which can be attributed primarily to uptake by phytoplankton and also submersed macrophytes, whereas $\mathrm{PO}_{4}$ decrease due to uptake was not visible each year as discussed above. A sharp decline in $\mathrm{NO}_{3}$ concentrations in the lake relative to river water at the beginning of the vegetation period may also indicate denitrification (Fig. 4). Concentrations of $\mathrm{N}_{\text {tot }}$ in lake waters were, on average, lower than in river waters, and thus we attribute this loss to denitrification, rather than to retention in the sediments, because no $\mathrm{P}_{\text {tot }}$ retention was observed during any of the measured periods. However, this estimation is rather rough. Denitrification intensity in a shallow lake rich in nitrate nitrogen and organic matter might be especially high in the sediment at the oxic/anoxic boundary $[4,26]$, despite high oxygen concentrations in pelagic waters. Rough calculation of $\mathrm{N}_{\text {tot }}$ load exported from the lake to the Baltic Sea on the basis of $\mathrm{N}_{\text {tot }}$ concentration measured in the lake water (1.81 $\mathrm{mg} \cdot \mathrm{dm}^{-3}$ ) gives a load by about $50 \%$ lower than total load entering the lake from the drainage area. Thus the lake is a substantial sink of nitrogen discharged by the Lupawa River and other inflows. Average annual concentrations in the lake water equaled only $20 \%$ of the $\mathrm{NO}_{3}$ concentration in the Łupawa River water. Wiśniewska [25], who calculat- 
ed the nutrient budget for Lake Gardno in 2008, estimated the retention of nitrogen in the lake equal to $38 \%$ of the incoming load (based on concentrations measured in the lake outlet in Rowy). It is likely that because of the loss of nitrogen due to denitrification, no correlation between TSM concentrations and nitrogen compounds was found.

\section{Limitation of Primary Production}

Internal modification of nutrient concentrations controlled by physical (resuspension, mixing) and biological (nitrogen fixation, denitrification, food web regeneration, uptake) processes can alter N-to-P ratio compared to the $\mathrm{N}$ to-P ratio of the loads introduced to the lake from the drainage basin $[1,2,27]$. In Lake Gardno the N-to-P ratio in a lake decreased relative to the river proportions due to loss of nitrogen. In the vegetation period mass N-to-P ratio dropped close to, or below, the "Redfield ratio" (mass 7:1), considered a typical cell proportion (at least for marine phytoplankton). Many authors indicate $\mathrm{N}_{\text {tot }}$ to $\mathrm{P}_{\text {tot }}$ in the range 5-10 as an indication of possible N-limitation of phytoplankton growth [27, 28], and point to nitrogen limitation during vegetation period in shallow lakes [29].

The degree and character of phytoplankton growth limitation in a lake can be estimated also from deviations between different trophic indices $[30,31] . \mathrm{TSI}_{\mathrm{chl}}-\mathrm{TSI}_{\mathrm{Ptot}}>$ 0 and $\mathrm{TSI}_{\mathrm{Ptot}}<\mathrm{TSI}_{\mathrm{Ntot}}$ is supposed to indicate phosphorus limitation, and by analogy $\mathrm{TSI}_{\mathrm{chl}}-\mathrm{TSI}_{\mathrm{Ntot}}>0$ and $\mathrm{TSI}_{\mathrm{Ptot}}>$ $\mathrm{TSI}_{\text {Ntot }}$ is supposed to indicate nitrogen limitation. For Lake Gardno, the vegetation period $\mathrm{TSI}_{\mathrm{chl}}-\mathrm{TSI}_{\mathrm{Ptot}}$ difference was negative, whereas $\mathrm{TSI}_{\mathrm{chl}}-\mathrm{TSI}_{\mathrm{TN}}$ was positive, which indicated that more chlorophyll was produced than indicated by $\mathrm{N}$ availability; pointing to a nitrogen deficiency in the growing season (Fig. 6). TSI $\mathrm{Ptot}_{\text {tot }}$ was always higher than

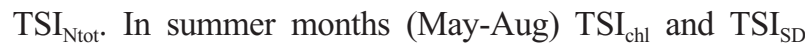
were almost equal (Fig. 6), thus chlorophyll concentrations were in accordance with light availability. In Fig. 6, TSI values stretching out to the right side of the Y-axis indicate greater transparency than predicted by chlorophyll concentrations in spring and fall $\left(\mathrm{TSI}_{\mathrm{chl}}>\mathrm{TSI}_{\mathrm{SD}}\right)$. This situation may occur if e.g. cyanobacteria dominate [30, 31]. During these periods species from the Oscillatoriaceae were very abundant and these species are known to achieve high biomass in shallow eutrophic lakes under extremely low light conditions $[32,33]$.

In summer, the phytoplankton community in Lake Gardno was dominated by cyanobacteria (Fig. 5), and this is a very common pattern in shallow, turbid lakes that are especially prone to cyanobacteria dominance $[32,33]$. Although it is still under discussion what factors might favour cyanobacteria [33], it is acknowledged that low N:P ratio promotes high proportions of cyanobacteria in the phytoplankton community, because cyanobacteria are believed to be better competitors for nitrogen than other algae [34]. Especially nitrogen-fixing species are thought to develop on the basis of surplus phosphorus in water. Smith [34] observed that cyanobacteria become rare in lakes with an $\mathrm{N}: \mathrm{P}$ mass ratio above 29 . In the present study different species dominated among cyanobacteria (Fig. 5), some potentially nitrogen-fixing (Anabena $s p$.), which might indicate nitrogen deficits in lake water. No correlation between cyanobacteria biovolume and N/P ratio was found, as during the vegetation period (April-October) the N-to-P mass ratio was always below 7 (Fig. 3), assumed to indicate nitrogen limitation [27, 28]. Presently low N-to-P ratio points to the need to decrease phosphorus loads discharged to the lake before further nitrogen reduction, if the N-to-P ratio is indeed a precondition for cyanobacteria blooms [35]. Such blooms are usually considered a nuisance to the lake ecosystem (non-edible to zooplankton, potentially toxic to other organisms) and to people (promoting high turbidity and forming surface accumulations, potentially toxic).

Light limitation of phytoplankton primary production in Lake Gardno can be indicated by the thickness of the euphotic layer estimated from phytoplankton primary production measured with the oxygen method. During 20 out of 26 measurement days, the euphotic layer was located above or at the lake bottom, and such days occurred throughout the year. There was no clear seasonal pattern of light limitation as presented in Fig. 4. Because the euphotic layer depth was negatively correlated to Chl $a$ and TSM, light conditions were largely controlled by concentrations of substance in water and changed on a day-to-day basis, a pattern often seen in shallow lakes [4, 29, 36, 37]. Thus it can be concluded that light and potentially also nitrogen were two factors limiting phytoplankton production during the vegetation period without an obvious seasonal trend.

\section{References}

1. KIEDRZYŃSKA E., WAGNER I., ZALEWSKI M. Quantification of phosphorus retention efficiency by floodplain vegetation and a management strategy for a eutrophic reservoir restoration. Ecol. Eng. 33, 15, 2008.

2. JAROSIEWICZ A., WITEK Z. Where do nutrients in an inlet-less lake come from? The water and nutrient balance of a small mesotrophic lake. Hydrobiologia 724, 157, 2014.

3. KOLADA A., SOSZKA H., CYDZIK D., GOŁUB M. Abiotic typology of Polish lakes. Limnologica 35, 145, 2005.

4. SCHEFFER M. Ecology of shallow lakes, $2^{\text {nd }}$ ed.; Kluwer Academic Publishers: Dordrecht, Boston, London, pp. 357, 2004.

5. PADISAK J., REYNOLDS C. S. Shallow lakes: the absolute, the relative, the functional and the pragmatic. Hydrobiologia 506/509, 1, 2003.

6. BURCHARDT L., GĄBKA M., KUCZYŃSKA-KIPPEN N., MESSYASZ B., NAGENGAST B., OWSIANNY P. M., PEŁCHATA A., PEŁCHATY M., STEFANIAK K., WIEŚCICKA I. Characteristics of the water ecosystems, In: Burchardt L. (Ed) Water ecosystems of the Słowiński National Park; Wydawnictwo Naukowe UAM, 2004 [In Polish].

7. SZYPER H. Quality of water in lakes, In: Burchardt L. (Ed) Water ecosystems of the Słowiński National Park; Wydawnictwo Naukowe UAM, 2004 [In Polish]

8. JAROSIEWICZ A. Seasonal Changes of Nutrient Concentration in Two Shallow Estuarine Lakes Gardno and Łebsko; Comparison, Baltic Coastal Zone 13, 121, 2009. 
9. TROJANOWSKI J. Various forms of phosphorus in bottom sediments of selected coastal lakes. Pol. Arch. Hydrobiol. 37, 341, 1990.

10. TROJANOWSKI J. Hydrochemistry, In: Mudryk Z. (Ed) Lake Gardno; Pomorska Akademia Pedagogiczna: Słupsk, 2003 [In Polish].

11. JĘDRASIK J., CYBERSKI J. The water exchange in estuarine lakes of the southern Baltic Sea as on the Gardno Lake example. Oceanol. Stud. 29, 43, 2000.

12. CIEŚLIŃSKI R. Short-term changes in specific conductivity in Polish coastal lakes (Baltic Sea basin). Oceanologia 55, 639, 2013.

13. NAUSCH G., NEHRING D., NAGEL K. Nutrient concentrations, Trends, and Their Relation to Eutrophication, In: Feistel R., Nausch G., Wasmund N. (Eds) State and Evolution of the Baltic Sea 1952-2005; John Wiley \& Sons: Hoboken, New Jersey, 2008.

14. CIEŚLIŃSKI R. Changes in nutrient concentrations and loads in inflows entering Lake Gardno, In: Jankowski A. T., Absalon D., Machowski R., Ruman M. (Eds), Changes in water budgets in the evolving environment; Wydział Nauk o Ziemi UŚ: Katowice, 2009 [In Polish].

15. ELLWART A., CIEŚLIŃSKI R. Management of polder areas in drainage basins of selected coastal lakes, In: Bogdanowicz R., Fac-Beneda J. (Eds), Water resources and water protection. Water cycling in river chtchemnts; Fundacja Rozwoju Uniwersytetu Gdańskiego, 2009 [In Polish].

16. FICEK D., WIELGAT-RYCHERT M. Spatial distribution and seasonal variation in chlorophyll concentrations in the coastal Lake Gardno (Poland). Oceanol. Hydrobiol. Stud. 38, 3, 2009.

17. HERMANOWICZ W., W. DOŻAŃSKA, DOJLIDO J., KOZIOROWSKI B. Physico-chemical water and sewage analysis; Arkady: Warszawa, pp. 847, 1976 [In Polish].

18. JEFFREY S. W., HUMPHREY G. F. New spectrophotometric equation for determining chlorophyll a, b, c1 and c2. Biochem. Physiol. Pfl. 167, 191, 1975.

19. WIELGAT-RYCHERT M., RYCHERT M., FICEK D. Factors Controlling Pelagic Production and Respiration in a Shallow Polymictic Lake. Pol. J. Ecol. 58, 379, 2010.

20. PAWLIK M. Phytoplankton of the coastal Lake Gardno; Msc Thesis, Akademia Pomorska w Słupsku, pp. 71, 2009 [in Polish].

21. GORZEŃ, A., ZAŁUPKA A. Water quality of the Słupa River at Charnowo, Łupawa at Smołdzino, Łeba at Cecynowo in 2006-2008; Raport WIOŚ w Gdańsku delegatura w Slupsku: Słupsk, 2007, 2008, 2009 [In Polish].

22. ZASOBY WODNE KRAJU, Bulletin of the National Hydrological and Meteorological Service; IMGW: Warszawa, 2006, 2007, 2008 [In Polish].
23. JAROSIEWICZ A. Relationship between the total phosphorus concentration and organic matter in bottom sediments of Mały Borek lake (Bytów Lakeland). In: Marszelewski W. (Ed), Anthropogenic and natural transformations of lakes, Vol. 5; PTLim, UMK: Toruń, 2009 [In Polish].

24. KOWALCZEWSKA-MADURA K., GOŁDYN R. Internal loading of phosphorus from sediments of Swarzędzkie Lake (West Poland). Pol. J. Environ. Stud. 18, 635, 2009.

25. WIŚNIEWSKA K. Nutrient balance in Lake Gardno; Msc Thesis, Akademia Pomorska w Słupsku, pp 85, 2011 [In Polish].

26. TOMASZEK J.A. CZERWIENIEC E. Denitrification and oxygen consumption in bottom sediments: factors influencing rates of the processes. Hydrobiologia 504, 59, 2003.

27. KAMARAINEN A.M., PENCZYKOWSKI R. M., VAN DE BOGERT M.C., HANSON P.C., CARPENTER S.R. Phosphorus sources and demand during summer in a eutrophic lake Aquat. Sci. 71, 214, 2009.

28. ABELL J.M., ÖZKUNDAKCI D., HAMILTON D.P. Nitrogen and phosphorus limitation of phytoplankton growth in New Zealand lakes: implications for eutrophication control. Ecosystems 13, 966, 2010.

29. CHUBARENKO B, MARGOŃSKI P. The Vistula Lagoon, In: Schiewer U. (Ed) Ecology of Baltic Coastal Waters; Ecological Studies 197, Springer-Verlag: Berlin Heidelberg, 2008.

30. CARLSON R. E. A trophic state index for lakes. Limnol. Oceanogr. 22, 361, 1977.

31. CARLSON R. E., SIMPSON J. A coordinator's guide to volunteer lake monitoring methods; North American Lake Management Society, pp 96, 1996.

32. DOKULIL M. T., TEUBNER K. Cyanobacterial dominance in lakes. Hydrobiologia 438, 1, 2000.

33. SCHEFFER M., RINALDI S., GRAGNANI A., MUR L. R., VAN NES E. H. On the dominance of filamentous cyanobacteria in shallow, turbid lakes. Ecology 78, 272, 1997.

34. SMITH V. H. Low nitrogen to phosphorus ratios favor dominance of blue-green algae in lake phytoplankton. Science 221, 669, 1983

35. NÕGES T., LAUGASTE R., NÕGES P., TONNO I. Critical $\mathrm{N}$ :P ratio for cyanobacteria and $\mathrm{N}_{2}$-fixing species in the large shallow temperate lakes Peipsi and Vortsjarv, North-East Europe. Hydrobiologia 599, 77, 2008.

36. PAAVEL B., ARST H., REINART A. Variability of bio-optical parameters in two North-European large lakes. Hydrobiologia 599, 201, 2008.

37. ARST H., NÕGES T., NÕGES P., PAAVEL B. Relations of phytoplankton in situ primary production, chlorophyll concentration and underwater irradiance in turbid lakes. Hydrobiologia 599, 169, 2008. 
